\title{
UDC332.334.2
}

\section{PROBLEMS OF INSTALLATION WATER PROTECTIVE ZONES AND COASTAL PROTECTIVE STRIPES}

Rusina N., Candidate of Pedagogic Sciences, Technical department, lecturer

Lyul'chyk V., Candidate of Agricultural Sciences, Head of the technical department

Bida P., Candidate of Technical Sciences, Technical department, lecturer

Kachanovs'kyy O., Deputy Director for production work

Bulakevych S., Technical department, lecturer

Petrova O., Technical department, lecturer

SSS" Rivne Professional College of NULES of Ukraine"

E-mail: $\underline{\text { RusinaN@i.ua }}$

Annotation. The issue of establishing the boundaries of water protection and coastal stripes in Ukraine were examined in the article. The purpose of the study is to present the practical results of the formation the boundary delimiter of coastal protection stripes, based on scientific and methodological approaches to the development of land management projects for the establishment of coastal protection stripes and modern technologies in the area of geographic information system. Theoretical principles of establishing the boundaries of water protective zones and coastal protective stripes on water resources are analyzed. Regulatory basic documents on the subject of use in the establishment of water protection zones and coastal protection stripes have been explored. It is noted that the size of water protective zones and coastal protective stripes can be set in accordance with the provisions of the Land Code of Ukraine, and according to the especial projects in land management. It is suggested the procedure for establishing coastal and water protective zones is based on determining the hydrographic characteristics of water sites and morphological parameters of coastal areas using remote sensing data and geoinformation system and includes six steps: 1. Determination of morphometric parameters of water sites. 2. Obtaining relief data and its application 3.Determining the steepness of the slopes. 4. Construction of catchment areas and determination of surface effluent directions. 5. Creation of a buffer zone around water sites (construction of a protective stripe and a water protective zone). 6. Combining layers of informative maps for the final definition of boundaries. The use of the methodology is presented on a specific example, namely 
the pond in the village Gremyache, Rivne region. Methodology will provide a technical background for establishing and decision-making on the size of water protective zones and coastal protection stripes around water objects. One more aspect of the problem, solved by the methodology proposed in the article, involves informative supporting of decisions in a sphere of controlling water fund lands at the regional level as part of the planning measures for sustainable regions development and protection of water objects.

Key words: water protective zone, coastal protection belt, land management project, Earth remote sensing data of the Earth and geographic information system data, boundaries of the water protective zone and coastal protective stripe.

\section{Actuality:}

Strengthening of technological and anthropogenic impact on water bodies leads to deterioration of their ecological condition and degradation or impoverishment of the species composition of natural biocoenoses and hydrobiocoenoses, increased soil erosion. The current ecological condition of soils is also getting worse because of adverse changes in water regime, examples of which are soil salination, sodification and flooding of irrigated lands, overdrainage or overwetting of drained lands, etc. The lack of complexity in the land drainage has led to the fact that $43 \%$ of the land area with a drainage network has high level acidity; $7.6 \%$ - salined; $10.7 \%$ - overwetted; $12.8 \%$ are swampy [1].

The degree of ponds siltation reaches $20-50 \%$ of their design volume, and in some places they were silted completely. The banks of rivers are overgrown with bulrush, sedge grass and have lost their pronounced banks lineaments. In every region of Ukraine there are cases when coastal protection stripes are littered with household waste disposal, especially on the territory of settlements. Ponds and reservoirs of district that are not exploited, not leased are also not in proper condition too. As a result of such management reservoirs lose the drainage ability, natural properties, functions of supplying water for drinking and for household needs. Thus, establishing and ensuring compliance with the regime of water protection zones and coastal protection stripes are the most important tools to 
protect from the negative impact and improve the water and environmental situation and hydrological regime of the country.

Analysis of recent research and publications. The works of such scientists as S. Dubnyak, O. Kanash, A. Koshel, I. Kolganova, S. Osipchuk, M. Palamarchuk, V. Stashuk, A. Tomiltseva, M. Tomiltsev, M. Khvesyk, R. Filimonenko, V. Shevchuk, A. Jacyk and others are devoted to the issues of rational use and protection of water resources in Ukraine, as well as the formation of water protection restrictions in land usage. O. Dorosh, T. Yevsyukov, A. Martin, L. Perovych, and V. Sai reviewed water protection restrictions in their scientific researches. Let's draw our attention that the main indicators and parameters that determine the establishment of coastal protective stripes in modern economic conditions, are largely debatable, which requires doing further scientific researches $[2, \mathrm{p} .23]$.

The purpose of the study is to present the practical results of the formation the boundary delimiter of coastal protection stripes, based on scientific and methodological approaches to the development of land management projects for the establishment of coastal protection strips and modern technologies in the area of geographic information system.

Materials and methods of research. The study used methods of modeling, comparison and generalization, analysis and synthesis. The theoretical basis for the study were the up-to-date regulatory basis orders defining the subject of research in the field of geodesy and land management, including resolutions of the Cabinet of Ministers of Ukraine, methodologies(The system of methods and principles) and standards of the State Geocadastre of Ukraine. The material of the practical research was statistical materials of land distribution in Rivne region.

Research results and their discussion. In order to protect surface water sites from pollution and littering and to preserve their water content along rivers, around lakes, reservoirs and other water sites within the water protection zones, land plots are allocated for coastal protection stripes. 
Coastal protective stripes are established according to individual land management projects (paragraph2 part3 article60 Land legal Code of Ukraine).The normative legal foundation for the development of land management projects is the Land Code of Ukraine, the Water Code of Ukraine, the Law of Ukraine " On Land Management" and "On Land Protection", as well as the resolution of the Cabinet of Ministers of Ukraine dated 21.04.2021 № 411 "On amendments to the Procedure for determining the size and boundaries of water protective zones and the regime of commercial activity in them"; Building code 360-92** "Urban planning. Planning and construction of urban and rural settlements"; Standard of organization of Ukraine 00032632-005:2009 "Land management. Land management projects for the creation of water protective zones. Development rules "(approved by the order of the State Land Committee dated 17.07.2009 № 375); Methods of arranging water protective zones of rivers of Ukraine [3]; departmental building codes 33-4759129-03-05-92 "Design, arrangement and operation of water protection zones of reservoirs".

The title, composition and content of the land management project are determined by the customer taking into consideration the characteristics of the territory of a particular land management object. Theoretical principles of establishing the boundaries of water protection zones and coastal protection zones on the water sites are shown at the picture1 [1,p.80].

Particular attention should be taken into consideration the fact that on the lands under the coastal protective stripes are not situated objects of the water fund, but by their purpose they contribute to the functioning and proper exploitation of the water fund, perform certain protective functions. Accordingly, they are lands of the Ukrainian water fund and they are subject to a special procedure for their use and provision for use. 


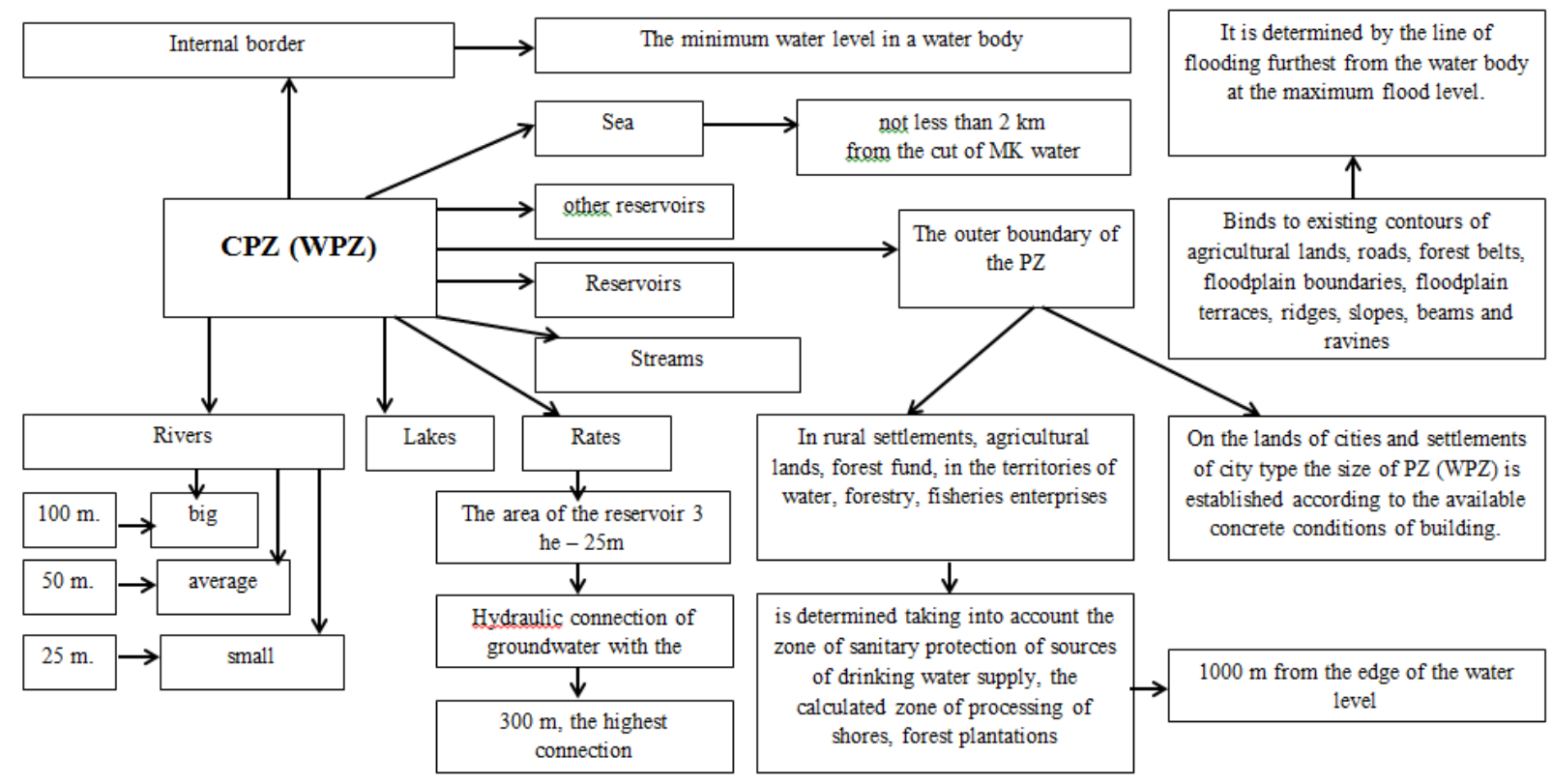

\section{Picture1. Theoretical principles of establishing the boundaries of water protective zones and coastal protective zones [1]}

Coastal protective stripes are established on land plots of all categories, except for maritime transport lands. According to the Law of Ukraine "On Land Management", the mandatory components of such projects are: "the task of drafting a land management project; explanatory note; characteristics of the territory with the establishment the regime of using the lands of water fund and water protective zones, restrictions on the use of lands and their regime of forming objects; materials of geodetic research and land management design; extract from the graphic part of the relevant urban planning documentation with the marked boundaries of the water protective zone, coastal protective stripe, beach area (if available); information about the perspective condition of land use and protection within the administrative-territorial unit, which is part of the scheme of land management and feasibility study of land use and protection of the relevant administrative-territorial unit (if any); plan of organization the territory with reflection of lands, landowners and land users, including land plots, in respect of which restrictions on use are established; plan of boundaries of land plots included in the territory of the water fund and water protective zones, boundaries of restrictions on the use of lands and their regime-forming objects without their withdrawal from landowners and land users; Schematics of the transfering into 
kind (on the ground) of the boundaries of the territory lands of the water fund and water protection zones, the boundaries of restrictions on the use of lands and their regime-forming objects; the act of transferring into kind (on the ground) the lands territory boundaries of the water fund and water protective zones, the boundaries of restrictions on the use of lands and their regime-forming objects; into kind (on the ground) list of restrictions in using of lands [4].

It should be noted that until January $1^{\text {st }}, 2025$, the size of coastal protective stripes within settlements may be changed by a detailed plan of the territory, which is consistent with the approved urban planning documentation. The specified land management project in this case is approved by the relevant village, settlement, city council. Outside the settlements, the boundaries of water protection zones are determined in accordance with land management projects or comprehensive plans for the territories spacious development of territorial communities[5].

One of the main stages in the territory organization of water protective zones is the establishment of land use regime, taking into consideration the composition of land, forms of land ownership and restrictions on economic activity. Legislative supporting of the establishment of water protective zones and coastal protective zones and land use regimes within them is represented by the Land and Water Codes, as well as other regulations.

The Water Code of Ukraine provides for a linear (geometric) approach to determining the outer boundaries of coastal protection stripes, according to which the width of the coastal protection stripe is set depending on the catchment waterway area, the size of reservoirs and slope steepness. Works on installation of protective stripes and water protection areas should be performed on the basis available large-scale planning-cartographic materials, geo-referenced data of the Earth and geospatial modeling, using the means of their processing geographic information system (ArcGis or analogues). This will avoid ambiguous interpretation and variability in project decisions. If it is necessary, the results are refined by performing full-scale research [7]. 
The procedure for establishing coastal and water protective zones is based on determining the hydrographic characteristics of water sites and morphological parameters of coastal areas using remote sensing data and geoinformation system and includes six steps(table1),[7].

\section{The method of establishing coastal and water protective zones with a help} of modern geoinformation system

\begin{tabular}{|c|c|}
\hline Step & \\
\hline $\begin{array}{l}\text { 1. Determination of } \\
\text { morphometric } \\
\text { parameters of } \\
\text { water sites. }\end{array}$ & $\begin{array}{l}\text { 1.1. Creating linear and polygonal objects (water object contours and } \\
\text { morphometric parameters) in ArcGis or its analogues. } \\
\text { 1.2. Creating segments using tracing } \\
\text { 1.3. Creating segments by digitizing vertices in streaming mode. } \\
\text { 1.4. Creating an object using an arbitrary line }\end{array}$ \\
\hline $\begin{array}{c}\text { 2.Obtaining reli } \\
\text { data and its } \\
\text { application }\end{array}$ & $\begin{array}{l}\text { The topographic model and the terrain model are two main representations of } \\
\text { these datum level. Terrain heights form a digital terrain model. The construction } \\
\text { of which takes place in stages: } \\
\text { 2.1. Selection of relief data sources by access sources (open using, commercial } \\
\text { offers, own organizations); } \\
\text { 2.2. Downloading data and saving them in TIFF format in the form of a regular } \\
\text { GRID scale } \\
\text { 2.3. Building a digital terrain model SRTM or in the Surfer program. }\end{array}$ \\
\hline $\begin{array}{r}\text { 3. Determ } \\
\text { steepnes } \\
\text { slop }\end{array}$ & $\begin{array}{l}\text { esses are determined based on a digital terrain model using ArcGIS } \\
\text { pe function. }\end{array}$ \\
\hline $\begin{array}{l}\text { 4. Construction of } \\
\text { catchment areas } \\
\text { and determination } \\
\text { of surface effluent } \\
\text { directions. }\end{array}$ & $\begin{array}{l}\text { Modeling hydrological characteristics of the rivers pool is performed by means of } \\
\text { the ArcGIS software with a help of Hydrology tool, the Spatial Analyst module. } \\
\text { 4.1. The dipping of the terrain territory is filling; } \\
\text { 4.2. The direction of river runoff is determined, that is cells where the runoff will } \\
\text { be directed are identified. } \\
\text { 4.3. Construction of a raster of cumulative runoff in each denticle. } \\
\text { 4.4. Watercourse cell identification. } \\
\text { 4.5. Definition of watercourse-links - segments of the flow channel. } \\
\text { 4.6. Assigning order to each link of the river runoff network. } \\
\text { 4.7. Construction of a raster, which contains the contours of all water-collecting } \\
\text { areas. }\end{array}$ \\
\hline $\begin{array}{l}\text { 5. Creation of a } \\
\text { buffer zone around } \\
\text { water sites } \\
\text { (construction of a } \\
\text { protective stripe } \\
\text { and a water } \\
\text { protective zone). }\end{array}$ & $\begin{array}{l}\text { The user can create a buffer around selected point, linear, or polygonal objects } \\
\text { using the Buffer command. } \\
\text { Algorithm for creating a buffer zone around an object. } \\
\text { a) Click the Edit tool on the Editor toolbar. (Editor). } \\
\text { b) Click on the object around which you want to create a buffer. } \\
\text { c) Click the Editor menu and select Buffer. } \\
\text { d) Enter the distance in map units for the buffer zone around the object } \\
\text { e) Select the location where the new object will be created. } \\
\text { f) Click OK. }\end{array}$ \\
\hline $\begin{array}{l}\text { 6. Combining } \\
\text { layers of } \\
\text { informative maps } \\
\text { for the final } \\
\text { definition of } \\
\text { boundaries. }\end{array}$ & $\begin{array}{l}\text { 6.1. Construction of a three-dimensional relief model according to the digital } \\
\text { relief model with a polygonal coating, which shows areas with a slope of more } \\
\text { than } 3^{\circ} \text {. Calculation of the water protection zone and spatial analysis of land use } \\
\text { within its boundaries } \\
6.2 \text {. Adjustment of the size of coastal protective stripes need to be carried out } \\
\text { according to high-resolution space pictures. } \\
6.3 \text {. Deciphering and establishing on the images of arable land, meadows and } \\
\text { pastures, areas covered with forests and making appropriate changes to the map of } \\
\text { coastal protective stripes. }\end{array}$ \\
\hline
\end{tabular}




\begin{tabular}{|l|l|}
\hline $\begin{array}{l}\text { 6.4. As a result of the carried out works the graphic part with drawings of water } \\
\text { protective borders zone and coastal protective stripe, functional zoning of the } \\
\text { territory and an analytical part with the project of local rules of building and land } \\
\text { use develops }\end{array}$ \\
\hline
\end{tabular}

The results of practical application the technique for the establishment of coastal protective stripes and water protective zones around the pond in Gremyache village of Rivne region are presented on the pictures 2 and 3.
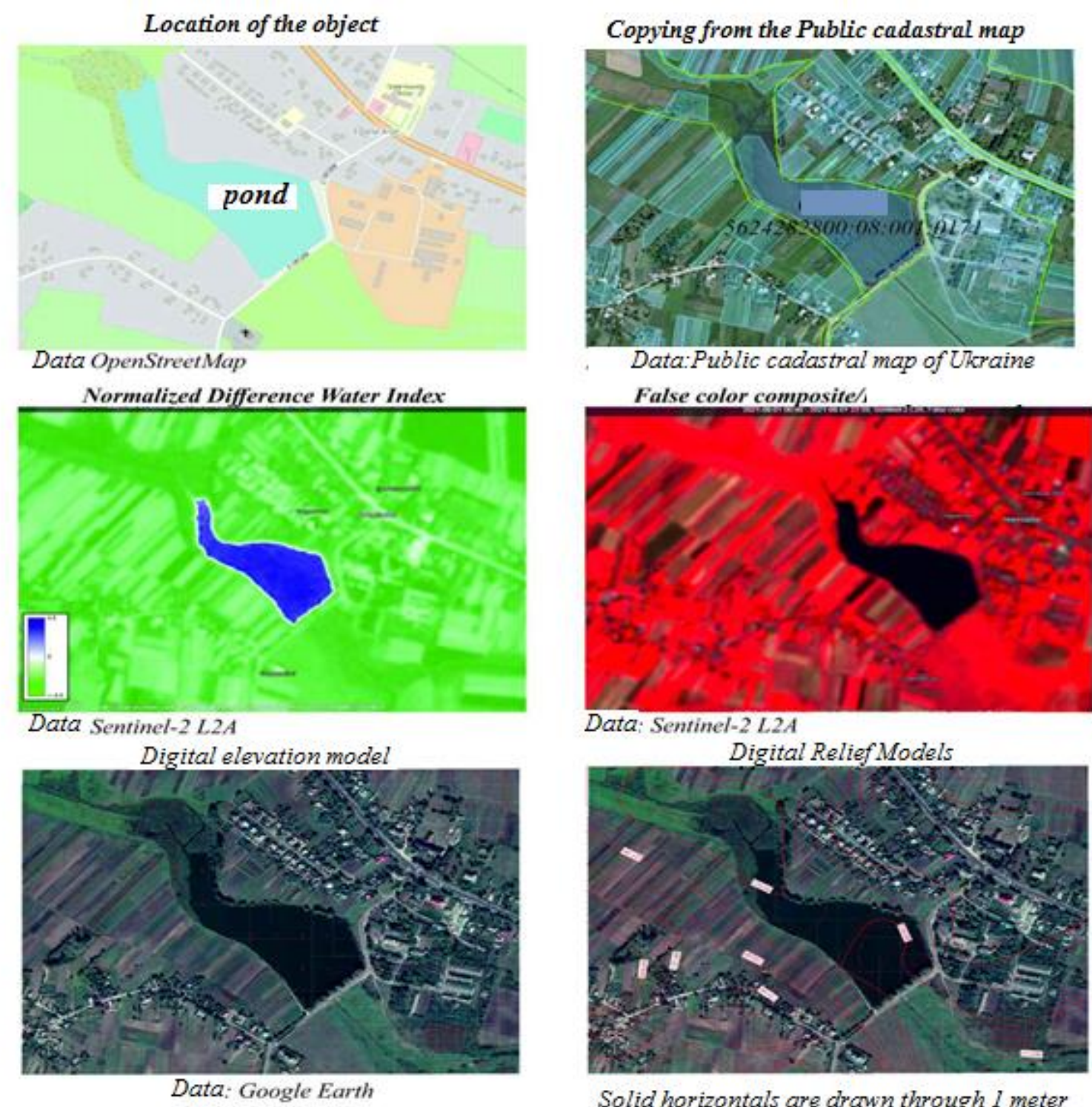

Solid horizontals are drawn through 1 meter

Picture 2. Scheme of installation coastal protective stripes and water protective zones around the pond in Gremyache village, Rivne region

Conclusions and prospects. The problems analysis of the establishing water protection and coastal stripes in Ukraine showed that in the conditions of 
increasing loads on the environment, development of social production and growth of material needs there is a need to develop and comply with special rules of water use, their rational use and protection. Establishment the boundaries of water protective and coastal stripes is carried out in accordance with land management projects as for the organizing and establishing the boundaries territories of water fund lands water protective zones. Their boundaries are indicated in land management documentation, urban planning documentation on the local and regional levels, and data is entered into the State Land Cadastre as information of restrictions in land using. The size of coastal protective stripes within settlements can be changed by a detailed plan of the territory.
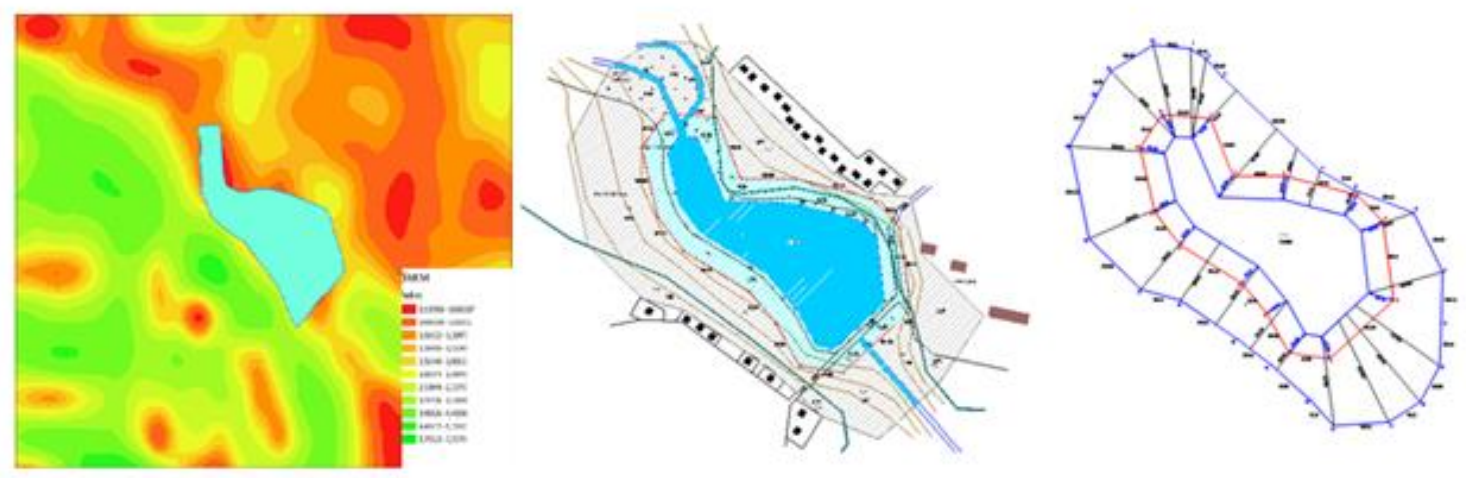

Picture 3. Cartogram of slope steepness, plan-scheme and layout drawing of the established boundaries water protective zone and the coastal protective stripe around the pond in Gremyache village, Rivne region

Thus, the establishment of the boundaries of water protective and coastal stripes is through a linear (geometrical) approach. The implementation of the approach involves taking into account the natural conditions of the territory, namely the relief. An effective method for determining the boundaries of water protective and coastal stripes is a method based on determining the hydrographic characteristics of water sites and morphological parameters of coastal areas with using remote sensing data and geoinformation system. 
In addition, it is necessary to conduct survey cadastral work taking into consideration a number of factors, including land prices, configuration and area of land piece.

\section{References}

1. Perovych L.M., Say V.M. (2017) Normatyvno-pravove ta heodezychne zabezpechennya kadastru zemel' vodnoho fondu [Regulatory and geodetic support of the cadastre of water fund lands]. L'viv, Ukrayina: Lviv Polytechnic Publishing House, 128.

2. Osypchuk S., Koshel' A., Kolhanova I. (2013) Naukovo-metodychni pidkhody do rozroblennya proektiv zemleustroyu shchodo vstanovlennya pryberezhnykh zakhysnykh smuh [Scientific and methodological approaches to the development of land management projects for the establishment of coastal protection strips] Land Management Bulletin, 7, 21-25.

3. Pokyd'ko I., Martyn A. (2012) Nova kontseptsiya formuvannya vodookhoronnykh obmezhen' u vykorystanni zemel'. [A new concept of formation of water protection restrictions in land use.] Land Management Bulletin, 7, 34-40.

4. Zakon Ukrayiny «Pro zemleustriy». Available at: https://zakon.rada.gov.ua/laws/show/858-15\#Text.

5. Kozlovs'ka L. Dlya vytrebuvannya zemel' pryberezhnoyi zakhysnoyi smuhy maye zastosovuvatysya vyklyuchno nehatornyy pozov [In order to review the land plot, coastal protection of complexity, it is necessary to interact with particularly bad lawsuits]. Available at: https://zib.com.ua/ua/142667dlya_vitrebuvannya_zemel_priberezhnoi_zahisnoi_smugi_mae_zas.html

6. Ol'khovs'ka O. (2021) Pro deyaki pytannya peredachi v orendu zemel' vodnoho fondu ta zberezhennya vodoym [On some issues of lease of water fund lands and preservation of reservoirs]. Land Management Bulletin, 6, 49-54.

7. Shevchuk S.A., Vyshnevs'kyy V.I., Kozyts'kyy O. M., Voroshnov S.M., Shevchenko I.A. Metodyka $\mathrm{z}$ vyznachennya mezh vodookhoronnykh zon, pryberezhnykh zakhysnykh smuh i smuh vidvedennya $\mathrm{z}$ osoblyvym rezhymom vykorystannya (z urakhuvannyam proektu zmin do Vodnoho Kodeksu Ukrayiny). Available at:

VODOOHORONNIH_ZON_PRIBEREZNIH_ZAHISNIH_SMUG_I_SMUG_VI DVEDENNA_Z_OSOBLIVIM_REZIMOM_VIKORISTANNA_Z_urahuvannam_ proektu_zmin_do_Vodnogo_Kodeksu_Ukraini

Русіна Н.Г., Люльчик В.О., Біда П.І., Качановський О.І., Булакевич С.В., Петрова О.М.

\section{ПРОБЛЕМИ ВСТАНОВЛЕННЯ МЕЖ ВОДООХОРОННИХ ЗОН ТА ПРИБЕРЕЖНИХ ЗАХИСНИХ СМУГ}

Анотація. У статті розглянуто питання встановлення меж водоохоронних та прибережних смуг в Украӥні. Метою дослідження є представлення практичних результатів формування меж прибережних захисних смуг, на 
підставі науково-методичних підходів до розроблення проектів землеустрою щзодо встановлення прибережних захисних смуг та сучасних ГІС технологій. Проаналізовано теоретичні засади встановлення меж водоохоронних зон та прибережних захисних смуг на водних об'єктах. Досліджено базові нормативно-правові документи, на предмет використання при встановленні водоохоронних зон та прибережних захисних смуг. Відзначено, щуо розмір водоохоронних зон та прибережних захисних смуг може бути встановлений відповідно до положень Земельного Кодексу Украӥни, так $i$ за окремими проектами із землеустрою. Запропоновано методику встановлення прибережних захисних смуг $i$ водоохоронних зон грунтується на визначенні гідрографічних характеристик водних об'єктів та морфологічних параметрів прибережних територій з використанням даних ДЗЗ і ГІС та включає шість кроків: 1. Визначення морфометричних параметрів водних об'єктів. 2. Отримання даних рельєфу та його застосування. 3. Визначення крутизни схилів. 4. Побудова водозбірних басейнів та визначення напрямків поверхневого стоку. 5. Створення буферної зони навколо водних об'єктів (побудова захисної смуги та водоохоронної зони). 6. Суміщення шарів інформативних карт для остаточного визначення меж. Використання методики представлено на конкретному прикладі, а саме ставок села Гремяче Рівненської області. Методика забезпечить технічне підтрунтя прийняття рішень щзодо встановлення розмір водоохоронних зон та прибережних захисних смуг навколо водних об'єктів. Ще один аспект проблеми, який вирішує запропонована в статті методика, полягає в інформаційній підтримці рішень з питань управління землями водного фонду на регіональному рівні як складової планування заходів для сталого розвитку регіонів і охорони водних об'єктів.

Ключові слова: водоохоронна зона, прибережна захисна смуга, проект землеустрою, дані ДЗз $і$ ГІС, межі водоохоронної зони та прибережної захисної смуги.

\section{Н.Г. Русина, В.А. Люльчик, П.И. Бида, О.И. Качановский, С.В. Булакевич, O.H. Петрова}

\section{ПРОБЛЕМЫ УСТАНОВЛЕНИЯ ГРАНИЦ ВОДООХРАННЫХ ЗОН И ПРИБРЕЖНЫХ ЗАЩИТНЫХ ПОЛОС}

Аннотация. В статье рассмотрены вопросы установления границ водоохранных и прибрежных полос в Украине. Целью исследования является представление практических результатов формирования гранич прибрежных защитных полос, на основании научно-методических подходов $\kappa$ разработке проектов землеустройства по установлению прибрежных зашчитных полос и современных ГИС технологий. Проанализированы 
теоретические основы установления границ водоохранных зон $и$ прибрежных защчитных полос на водных объектах. Исследованы базовые нормативно-правовые документы, на предмет их использования при установлении водоохранных зон и прибрежных защчитных полос. Отмечено, что размер водоохранных зон и прибрежных защчитных полос может быть установлен в соответствии с положениями Земельного Кодекса Украиньл, так и по отдельным проектам по землеустройству. Предложенная методика установления прибрежных защзитных полос и водоохранных зон основывается на определении гидрографических характеристик водных объектов и морфологических параметров прибрежных территорий $с$ использованием данных ДЗЗ и ГИС и включает иесть этапов: 1. Определение морфометрических параметров водных объектов. 2. Получение данных рельефа и его применения. 3. Определение крутизны склонов. 4. Построение водосборных бассейнов и определение направлений поверхностного стока. 5. Создание буферной зоны вокруг водных объектов (построение защчитной полосы и водоохранной зоны). 6. Совмещчение слоев информативных карт для окончательного определения границ. Использование методики представлено на конкретном примере, а именно ставок села Гремячий Ровенской области. Методика может обеспечивать техническое основание принятия решений об установлении размер водоохранных зон и прибрежных зашчтнных полос вокруг водных объектов. Еще один аспект проблемь, который решает предложенная в статье методика заключается в информационной поддержке решений по управлению землями водного фонда на региональном уровне как составляющая планирования мероприятий для устойчивого развития регионов и охраны водных объектов.

Ключевые слова: водоохранная зона, прибрежная защчитная полоса, проект землеустройства, даннье ДЗЗ и ГИС, гранищьы водоохранной зонь и прибрежной защчитной полосы.

Ключевые слова: водоохранная зона, прибрежная защуитная полоса, проект землеустройства, данные ДЗЗ и ГИС, гранищзы водоохранной зонь и прибрежной защчитной полосы. 